An interesting explanation is given for the decline of the tuberculosis death-rate: when the rate is high more females die than males; but as the rate falls the sexes are equally affected, as in England about 1860 ; thereafter the male death-rate begins to exceed the female. This, it is said, is due to the deaths of females during the child-bearing period and the result is a reduction of the number of susceptible families. This point is well worth remembering when assessing the value of control measures over a number of years.

More light is thrown on the vexed question of tuberculosis in consorts. It is known that a large proportion of exposed consorts do in fact develop the disease, but that others remain well. The family history of exposed consorts shows that those whose families are tuberculous show a higher incidence of the disease than those whose families are free from tuberculosis. It is emphasized that to know the true picture for children they must be followed up after they leave the home.

In a concise summary the author outlines how better methods of control could be instituted by a more comprehensive case-finding campaign based on information about those persons known to have tuberculosis and about susceptible families. Surprisingly, mass miniature radiography is not discussed; it is by this method above all others that much wider groups can now be examined than ever before.

Although it offers nothing outstanding in the way of new discoveries, this book succeeds in its aim of throwing more light on the problems of susceptibility to tuberculosis, and it includes a really remarkable amount of useful information in just over a hundred pages. The volume is well written and presented, the graphs and tables are clear and easy to understand, and a full bibliography is included. All concermed in the control of tuberculosis-public health officers, tuberculosis officers, health visitors, social workers general practitioners, and medical research workers - should find much to interest them in its pages.

\section{THE CHILD'S BLOOD IN HEALTH AND DISEASE}

\section{Atlas of the Blood in Children}

By Dr. Kenneth D. Blackfan and Dr. Louis K. Diamond. Pp. xiv +320 (70 plates). (New York: Commonwealth Fund; London : Oxford University Press, 1944.) 66s. 6d. net.

ATHOUGH we have long been accustomed to A coloured illustrations in text-books and monographs on hæmatology, we find in this "Atlas of the Blood in Children" something above the ordinary not only in its extent, but also and more especially in the happy combination of faultless artistry and perfect colour-printing. The very slight variation in colouring due to the routine use of Wright's stain in place of those more commonly used in Great Britain, namely, Leishman or Giemsa, does not detract in the slightest from the value of the seventy plates used to illustrate the important features of the blood pictures of more than five thousand cases examined and catalogued by the authors in their special hæmatological laboratory in the Infants' and Children's Hospitals, Boston. A special point is made of the fact that the "Atlas" is not intended as an exhaustive treatise on the variations in the blood in diseases of children, but represents only conditions with which the authors have had close personal experience. This will explain some omissions, and also the apparently undue stress laid on diseases seldom seen in Britain, such as Meditteranean anæmia and sickle cell anæmia.

The text deals with the hæmatology of childhood in five main sections : the blood cells; anæmias; the leucocytes in disease; the leukæmias; the platelets. The first section has much valuable information, but will be spoilt for most British readers by its use of the term 'megaloblast' for the parent cell in the normal development of the red blood corpuscles. Once the necessary mental adjustment has been made to allow for this divergence from hæmatological nomenclature in Britain, the rest of this, and of the succeeding section on the erythrocytes in anæmia, can be read with real pleasure and much profit. The authors have adopted a purely morphological basis for the classification of the anæmias, which, though somewhat outdated, lends itself admirably to a treatise in which pictorial representation of the blood as seen in stained films is the raison d'être of the publication. The inclusion of a separate group of "Anaemias often associated with Jaundice", though inconsistent with this classification, has its points clinically.

The section on "The Leucocytes in Disease" has much valuable observation condensed in the fow pages devoted to it. Particularly valuable are the full descriptions of significant blood pictures in pulmonary tuberculosis and infectious mononucleosis. In the section on leukxmia there is perhaps an overelaboration of olinical types and too facile a dismissal of the value of marrow puncture. The last section, on the platelets, is adequate, but contains an inexplicable confusion between Henoch's and Schönlein's purpura. This lapse will certainly cause the authors no heart-burnings, since they rightly dismiss these subdivisions of purpura as of little real significance.

The "Atlas" and its text are obviously intended primarily for the practising pediatrician and his hæmatologist. Full case histories of selected illustrative examples of the various disease states are included but are not overdone. Commendable restraint is also exercised in the details of laboratory data, particularly in the matter of descriptions of the blood picture presented, the very realistic coloured plates of blood films taking the place of these descriptions. There is little attempt at discussion of debatable theories and hypotheses, and if this does at times result in the apparently uncritical acceptance of views still sub judice, it certainly leads to brevity. There is a healthy insistence on the practical in both treatment and investigation, and the dangers and advantages of blood transfusions receive frequent and carefully considered mention. The sequence of the illustrations follows that of the text, and each plate is faced by an outline drawing on which the characteristic or abnormal cells are numbered for detailed reference in the descriptive legends. The printing is excellent, the style easy and the indexing satisfying.

This joint produrction by the clinician, the laboratory hæmatologist and the artist is one which goes a long way towards filling a serious gap in the bookshelves of pediatricians and clinical pathologists, and can be warmly commended not only to these but also to all who have any contact with hæmatology in general or with children in any branch of medical practice.
Thos. B. Davie. 